10 - ORIGINAL ARTICLE

CLINICAL INVESTIGATION

\title{
The Glasgow Prognostic Score. An useful tool to predict survival in patients with advanced esophageal squamous cell carcinoma ${ }^{1}$
}

\author{
Maria Aparecida Coelho de Arruda Henry', Mauro Masson Lerco ${ }^{\mathrm{II}}$, Walmar Kerche de Oliveira ${ }^{\mathrm{II}}$, Anderson Roberto Guerra ${ }^{\mathrm{II}}$, \\ Maria Aparecida Marchesan Rodrigues ${ }^{\mathrm{IV}}$ \\ DOI: http://dx.doi.org/10.1590/S0102-8650201500800000010 \\ IPhD, Full Professor, Department of Surgery, Gastroenterology Surgery Division, Botucatu Medical School, Universidade Estadual Paulista (UNESP), \\ Brazil. Conception and design of the study, acquisition and interpretation of data, critical revision. \\ IIPhD, Assistant Professor, Department of Surgery, Gastroenterology Surgery Division, Botucatu Medical School, UNESP, Botucatu-SP, Brazil. \\ Acquisition of data.

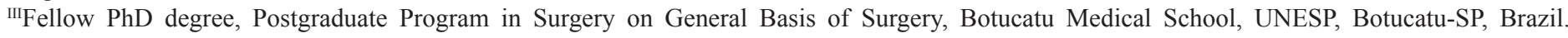 \\ Acquisition of data. \\ ${ }^{\text {IV }} \mathrm{PhD}$, Full Professor, Investigative Pathology Division, Department of Pathology, Botucatu Medical School, UNESP, Botucatu-SP, Brazil. Interpretation \\ of data, drafting the article, critical revision.
}

\begin{abstract}
PURPOSE: To evaluate the usefulness of the Glasgow Prognostic Score (GPS) in patients with esophageal carcinoma (EC).

METHODS: A total of 50 patients with EC were analyzed for GPS, nutritional and clinicopathologic parameters. Patients with CRP $\leq$ $1.0 \mathrm{mg} / \mathrm{L}$ and albumin $\geq 3.5 \mathrm{mg} / \mathrm{L}$ were considered as GPS $=0$. Patients with only CRP increased or albumin decreased were classified as GPS $=1$ and patients with $\mathrm{CRP}>1.0 \mathrm{mg} / \mathrm{L}$ and albumin $<3.5 \mathrm{mg} / \mathrm{L}$ were considered as GPS $=2$.

RESULTS: GPS of 0, 1 and 2 were observed in seven, 23 and 20 patients, respectively. A significant inverse relationship was observed between GPS scores and the survival rate. The survival rate was greatest in patients with GPS $=0$ and significantly higher than those from patients with GPS=1 and GPS=2. Minimum 12-month survival was observed in $71 \%$ patients with GPS $=0$ and in $30 \%$ patients with GPS $=1$. None of the patients with GPS=2 survived for 12 months. A significant relationship between CRP or albumin individually and the survival rate was observed. No significant relationship among nutritional, clinic pathological parameters and survival was found. CONCLUSION: Glasgow Prognostic Score is an useful tool to predict survival in patients with esophageal carcinoma.
\end{abstract}

Key words: Esophageal Neoplasms. Neplasms, Squamous Cell. Glasgow Outcome Scale. 


\section{Introduction}

Esophageal cancer is the fourth leading cause of cancer-related mortality in Brazil ${ }^{1}$. The main histological type is squamous cell carcinoma, comprising about $90 \%$ of all esophageal carcinomas in our country ${ }^{1}$. The diagnosis is usually made at advanced stages, which explains the high mortality rate ${ }^{2}$.

The survival of patients with esophageal cancer submitted to surgery has been widely evaluated ${ }^{3-7}$, but few studies have investigated the clinical evolution of patients with advanced esophageal cancer ${ }^{8,9}$.

Recent reports have demonstrated that systemic inflammation, expressed by high levels of serum-C reactive protein can predict the survival of patients with cancer ${ }^{10-12}$. The Glasgow Prognostic Score is an inflammation-based prognostic score used as a predictive index of survival for patients with advanced cancer, including gastrointestinal carcinomas ${ }^{12}$. It is a simple prognostic indicator based on the serum levels of albumin and $\mathrm{C}$ reactive protein. It is calculated as follows: a score of 0 for normal $\mathrm{C}$ reactive protein and albumin levels, score 1 for either an abnormal $\mathrm{C}$ reactive protein or abnormal albumin level and score 2 for both abnormal $\mathrm{C}$ reactive protein and abnormal albumin levels ${ }^{11}$.

The aim of this retrospective study was to evaluate the usefulness of the Glasgow Prognostic Score as a predictive factor of survival in a cohort of patients with advanced esophageal squamous cell carcinoma under palliative clinical care.

\section{Methods}

This study was approved by the Research Ethics Committee of Botucatu Medical School, UNESP.

In this retrospective study, medical records of 50 patients with esophageal cancer, referred to the Botucatu University Hospital (BUH), UNESP, from January 2010 to December 2013, were analysed. Patient inclusion criteria were: esophageal squamous cell carcinoma stages III or IV (TNM classification) of either sex and any age. Exclusion criteria were: squamous cell carcinoma stages I and II, esophageal adenocarcinoma, occurrence of infection or inflammatory disease. The analysis of the patients' medical records allowed the evaluation of the following parameters:

1. Demographics: age, sex, race.

2. Nutritional condition: Body Mass Index (BMI, kg/ $\mathrm{m}^{2}$ ), calculated from the weight and height using Cronk \& Roche's formula ${ }^{13}$ : BMI $=$ weight divided by the squared height in meters. The collected data were compared to reference values.
3. Percent weight loss ( $\% \mathrm{WL})$ was calculated from the usual body weight reported by the patient and the actual body weight using the formula: $\% \mathrm{WL}=$ (usual body weight - actual body weight $\mathrm{x} 100$ ) divided by the actual body weight. A weight loss over $10 \%$ was considered severe according to the criteria proposed by Blackburn et al. ${ }^{14}$.

4. Biochemical Evaluation: Serum albumin and C reactive protein levels were determined by automatic methods in the Biochemistry Laboratory of the BUH, Clinical Analysis Sector. The obtained values were compared to the reference data.

5. The Glasgow Prognosis Score (GPS) was based on the serum levels of albumin and C-reactive protein $(\mathrm{CRP})^{11}$. It was calculated as follows: Patients with both normal CRP $(\leq 1.0 \mathrm{mg} /$ $\mathrm{dL})$ and albumin $(\geq 3.5 \mathrm{mg} / \mathrm{dL})$ levels were allocated a score of 0 . Patients with either an abnormal $\mathrm{C}$ reactive protein or abnormal albumin level were allocated a score of 1 and patients with both an elevated CRP $(>1.0 \mathrm{mg} / \mathrm{dL})$ and hypoalbuminemia $(<3.5 \mathrm{mg} / \mathrm{dL})$ were allocated a score of 2 .

6. Tumor site and histopathology were determined by endoscopic evaluation and biopsy reports.

7. Clinical Tumor Staging was performed based on tomographic exams of the thorax and abdomen (TNM/ UICC classification - National Cancer Institute, 2012).

8. Survival rate was evaluated considering the time between endoscopic diagnosis and patient death or last interview.

\section{Results}

\section{Demographics}

The study included 50 patients with advanced esophageal squamous cell carcinoma stages III and IV, under palliative clinical care. The demographics are summarized on Table 1. Forty eight patients were male (96\%) and 2 female, aged 38-81 years (median age 60.9 years). $56 \%$ of the studied population was older than 60 .

\section{Nutritional condition}

A) Body Mass Index: BMI of the study population ranged from 14.1 to $37.3 \mathrm{~kg} / \mathrm{m}^{2}$, with a mean body surface of $20.02 \pm 4.74 \mathrm{~kg} / \mathrm{m}^{2}$ (Table 1 ). Twenty two patients (44\%) were undernourished and had BMI lower than $18.5 \mathrm{~kg} / \mathrm{m}^{2}$. Eutrophic patients $\left(56 \%\right.$, IMC $\left.\geq 18.5 \mathrm{~kg} / \mathrm{m}^{2}\right)$ had a 12 -month survival of $28.57 \%$ and in undernourished patients it was $13.6 \%$ in relation to the study population. The Spearman correlation test did not show a significant correlation between BMI and survival (Table 2, $\mathrm{p}<0.3$ ). 
B) The percent weight loss: \%WL mean value was $18.4 \pm 9.1 \%$, with extremes of zero and $37.5 \%$. There was no significant relationship between $\% \mathrm{WL}$ and the survival rate. The percent weight loss was greater than $10 \%$ (undernourished) in $82 \%$ patients, $19.5 \%$ of which had minimal survival of 12 months. Thirty three percent of the patients were eutrophic $(\% \mathrm{WL}<10 \%)$ and all had 12-month survival $(\mathrm{p}<0.6)$.

\section{The Glasgow Prognosis Score (GPS)}

GPS of 0,1 and 2 were observed in seven, 23 and 20 patients, respectively (Table 1). A significant inverse relationship was observed between GPS scores and the survival rate $(\mathrm{p}<0.001$, Table 3). The survival rate was greatest in patients with GPS $=0$ $(20.5 \pm 8.8$ months $)$ and significantly higher $(<0.001)$ than those from patients with GPS $=1(8.8 \pm 5.5$ months $)$ and GPS $=2(3.2 \pm 2.5)$.

Minimum 12-month survival was observed in $71 \%$ patients with GPS $=0$ and in $30 \%$ patients with GPS $=1$. None of the patients with GPS $=2$ survived for 12 months $(p<0.001$, Table 4$)$.

\section{Serum albumin}

Serum albumin levels ranged from 1.6 to $4.8 \mathrm{mg} / \mathrm{dL}$, with a mean of $3.4 \pm 0.7 \mathrm{mg} / \mathrm{dL}$ (Table 1 ). Fifty percent of the patients presented normal serum albumin levels. A significant relationship was observed between serum albumin levels and the survival rate $(p<0.001$, Table 2$)$. Forty percent of the patients with normal albumin levels survived for at least 12 months, while only $4 \%$ of the patients with low albumin levels survived for 12 months $(\mathrm{p}<0.006$, Table 4).

\section{Reactive Protein (CRP)}

Serum-C reactive protein levels ranged from 0.2 to 40.3 $\mathrm{mg} / \mathrm{dL}$ with a mean of $7.8 \pm 10.2 \mathrm{mg} / \mathrm{dL}$ (Table 1). A significant relationship was observed between CRP levels and the survival rate $(\mathrm{p}<0.001$, Table 2$)$. Most patients $(\mathrm{n}=41)$ presented high CRP values and only five patients (12\%) with high CRP levels survived for at least 12 months. From the nine patients with normal CRP levels, five $(55.5 \%)$ survived for at least 12 months $(\mathrm{p}<0.01$, Table 4$)$.

\section{Tumor site}

Endoscopically, the tumor was located in the middle third of the esophagus in the majority of patients $(n=30)$. Tumor was in the upper $(n=10)$ or at the distal third of the esophagus in
10 patients $(\mathrm{p}<0.0001)$. Survival rate did not differ significantly in relation to tumor site (Table 4 ).

\section{Staging}

Most patients $(n=35)$ were in stage IV $\left(\mathrm{T}_{\mathrm{x}} \mathrm{N}_{\mathrm{x}} \mathrm{M}_{1}\right)$ and 15 patients were in stage III $\left(\mathrm{T}_{3} \mathrm{~N}_{1} \mathrm{M}_{0}\right)(\mathrm{p}<0.0001)$. There were no significant differences on the 12-month survival rates between patients in stages III and IV (Table 4).

TABLE 1 - Clinicpathological features of patients with advanced esophageal squamous cell carcinoma $(n=50)$.

\begin{tabular}{cc}
\hline Sex ratio, male/female & $48 / 2$ \\
Median age (range), years & $60.92 \pm 10.04(38-81)$ \\
Median BMI (range), $\left(\mathrm{kg} / \mathrm{m}^{2}\right)$ & $20.02 \pm 4.74(14.1-37.3)$ \\
Median WL (range), $\%$ & $18.47 \pm 9.17(0-37.5)$ \\
Median Albumin (range), $\mathrm{mg} / \mathrm{dL}$ & $3.46 \pm 0.74(1.6-4.8)$ \\
Median CRP (range), $\mathrm{mg} / \mathrm{dL}$ & $7.80 \pm 10.25(0.20-40.30)$ \\
Glasgow Prognostic Score & \\
(GPS) & 7 \\
GPS $=0$ & 23 \\
GPS $=1$ & 20 \\
GPS $=2$ & \\
Tumor Site & 10 \\
Upper & 30 \\
Middle & 10 \\
Lower & \\
Tumor Stage & 35 \\
III & \\
IV & $8.26 \pm 7.62(1-38)$ \\
Global Survival (months) & \\
\hline
\end{tabular}

$\mathrm{BMI}=$ Body Mass Index, WL=Leight Loss, $\mathrm{CRP}=\mathrm{C}$ Reactive Protein.

TABLE 2 - Correlation among survival, Glasgow Prognostic Score, Albumin, CRP and nutritional variables.

$\mathrm{p}$

$\begin{array}{cc}\text { Survival vs GPS } & 0.0001 \\ \text { Survival vs Albumin } & 0.0010 \\ \text { Survival vs CRP } & 0.0011 \\ \text { Survival vs BMI } & 0.3676 \\ \text { Survival vs \% WL } & 0.1961\end{array}$

Spearman Correlation. 
TABLE 3 - Survival rate (months) in patients with Glasgow Prognostic Score 0, 1 and 2.

\begin{tabular}{ccc}
\hline GPS & n & Survival rate (months) \\
\hline 0 & 7 & $20.57 \pm 8.84 \mathrm{a}$ \\
1 & 23 & $8.86 \pm 5.56 \mathrm{~b}$ \\
2 & 20 & $3.25 \pm 2.55 \mathrm{c}$
\end{tabular}

$\mathrm{p}<0.00001$.

TABLE 4 - Correlation among 12-month survival, GPS and clinicpathological features in patients with advanced esophageal cancer $(n=50)$.

\begin{tabular}{lcc}
\hline Variable & 12-month survival & \\
\hline Glasgow Prognostic & & \\
Score(GPS) & $71 \%$ & $\mathrm{p}=0.001$ \\
$\mathrm{GPS}=0$ & & \\
$\mathrm{GPS}=1$ & $30 \%$ & \\
$\mathrm{GPS}=2$ & $0 \%$ & $\mathrm{P}=0.006$ \\
Hypoalbuminaemia & $4 \%$ & \\
Normoalbuminaemia & $40 \%$ & $\mathrm{P}=0.35$ \\
BMI $<18.5$ & $13.6 \%$ & \\
BMI $>18.5$ & $28.0 \%$ & $\mathrm{p}=0.64$ \\
$\%$ WL $\geq 10$ & $19.5 \%$ & \\
$\quad \%$ WL $<10$ & $33.3 \%$ & $\mathrm{p}=0.01$ \\
CRP $\leq 1$ & $55.5 \%$ & \\
CRP $>1$ & $12.1 \%$ & $\mathrm{p}=0.78$ \\
Stage III & $26.6 \%$ & \\
Stage IV & $20.0 \%$ & $\mathrm{p}=0.20$ \\
Tumor Site & & \\
Upper & $10 \%$ & \\
Middle & $20 \%$ & \\
Lower & $40 \%$ & \\
\hline $\mathrm{p}$ i & & \\
\hline
\end{tabular}

$\mathrm{p}$ indicates significance according to chi-square test.

\section{Discussion}

This study investigated the usefulness of the Glasgow Prognostic Score, which is an inflammation-based prognostic score, to predict survival in a cohort of patients with advanced esophageal squamous cell carcinoma under palliative clinical care.

The high incidence of advanced esophageal cancer in male patients $(96 \%)$ observed in our study has been reported in other studies ${ }^{3,15,16}$. Patient mean age (60 \pm 10 years old) in our series of cases was lower than that reported by Ando et al. ${ }^{7}$ and Eloubeidi et al. ${ }^{17}$.
Anthropometric nutritional evaluation revealed a mean BMI of $20.2 \pm 4.7 \mathrm{~kg} / \mathrm{m}^{2}$ body surface. However, 22 patients (44\%) were protein-energy undernourished and presented a BMI lower than $18.5 \mathrm{~kg} / \mathrm{m}^{2}$ due to the tumor and the ensuing esophageal obstruction and alimentary alteration. In this group, only three patients (13.6\%) survived 12 months or longer. In eutrophic patients $8(28 \%)$ presented 12-month survival. No correlation was found between BMI and survival rate by the Spearman test.

The mean involuntary percent weight loss in the period of six months before diagnosis was $18.4 \pm 9.1 \%$. Severe undernourishment $(\% \mathrm{WL}>10 \%)$ was diagnosed in 41 patients $(82 \%)$. Although no correlation has been found between severe undernourishment and survival rate, undernourished patients had a survival rate of 12 months of $19.5 \%$. In eutrophic patients, the minimal survival rate of 12 months was $33.3 \%$ of the study population. Our results are in agreement with recent studies on patients with esophageal and stomach cancer, that revealed no correlation between nutritional condition and survival ${ }^{18}$, but are in contrast to reports of poorer chemotherapy response and shorter survival in patients with weight loss ${ }^{19}$.

Considering that cancer patients are in a chronic inflammation condition ${ }^{20}$, the Glasgow Prognostic Score has been used to classify the degree of inflammation based on the serum levels of $\mathrm{C}$ reactive protein and albumin ${ }^{10-12,18}$.

In the present study we have evaluated the Glasgow Prognostic Score (GPS) in a homogeneous population of fifty patients with advanced esophageal squamous cell carcinoma submitted only to palliative clinical treatment, gastrostomy or jejunostomy, in association with chemotherapy and radiotherapy.

Global patient survival in our study was $8.2 \pm 7.6$ months. It is similar to that reported in patients with advanced esophageal cancer submitted to two types of palliative treatment, self expandable metallic stent or isoperistaltic gastric tube ${ }^{21}$. However, when the GPS score was considered, a significant inverse relationship was observed between GPS scores and the survival rate $(\mathrm{p}<0.001)$. The survival rate was greatest in patients with GPS $=0$ (20.5 \pm 8.8 months $)$ and significantly higher (< $0.001)$ than those from patients with GPS $=1(8.8 \pm 5.5$ months $)$ and GPS $=2$ (3.2 \pm 2.5 months). We have observed that $71 \%$ patients with GPS $=0$ survived for at least 12 months, while $30 \%$ of patients with GPS $=1$ and none of the patients with GPS=2 survived for 12 months $(p<0.001$, Table 4$)$. Our results on patient survival are higher than those reported by Crumley et al. ${ }^{22}$ and Silva et al. ${ }^{18}$.

In our study, the majority of patients $(n=43)$ had a GPS of 1 and 2 than aPS $=0(n=7)$, which matches with the advanced 
stage of the disease in this cohort of patients analysed. Similar results were reported by Wang et al. ${ }^{15}$.

Out of the 50 patients analyzed, 30 had the tumor in the middle third of the esophagus, 10 in the upper and 10 in the lower third of the esophagus. The preferential tumor site observed in our study is similar to the reported by most authors ${ }^{3,5,7}$. As expected, there were no relationship between tumor site and patient survival.

As to staging, most patients in this series $(70 \%)$ were in stage IV and the others were in stage III (30\%). The 12-month patient survival of the two groups did not differ significantly $(p=0.7)$. This result was not surprising since both groups were in advanced stages of the disease.

In the present study most patients $(n=41)$ presented high values of $\mathrm{C}$ reactive protein and from these only five patients survived for at least 12 months $(p<0.001$, Table 2$)$. This finding highlights the sensitivity of this biomarker of inflammation to predict survival in patients with cancer, as previously reported ${ }^{8,15,23}$.

Interestingly, half of the patients $(n=25)$ with advanced esophageal cancer presented normal albumin levels and from these, $40 \%$ patients survived for at least 12 months, while only $4 \%$ of the patients with low albumin levels survived for 12 months ( $p<0.006$, Table 4). These results emphasize that albumin concentrations on its own are associated with survival in cancer patients ${ }^{24}$.

\section{Conclusion}

The Glasgow Prognostic Score (GPS), which is based on the serum levels of $\mathrm{C}$ reactive protein(CRP) and albumin, is an useful prognostic factor of survival for patients with advanced esophageal squamous cell carcinoma. Considering the low cost and the availability of $\mathrm{C}$ reactive protein and albumin testing, we recommend the use of the GPS score as a routine evaluation procedure to predict survival in patients with advanced esophageal cancer.

\section{References}

1. Instituto Nacional de Câncer. Estimativas 2014: Incidências de câncer no Brasil. [Internet] Rio de Janeiro: INCA; 2015. Disponível em http:\|www.inca.gov.br/estimativa2014(Book).

2. Enzinger PC, Mayer RJ. Esophageal cancer. N. Engl J Med. 2003 Dec 4;349(23):2241-52. PMID: 14657432.

3. Liu J, Xie X, Zhou C, Peng S, Rao D, Fu J. Which factors are associated with actual 5-year survival of oesophageal squamous cell carcioma? Eur J Cardiothorac Surg. 2012 Mar;41:e7-e11. doi: 10.1093/ejcts/ezr240.

4. Rosa AR, Gurski RR, Schirmer CC, Brentano L, Kruel CD. Survival and prognostic factors in patients with resected epidermoid esophageal carcinoma. Int Surg. 1999 Jul-Sep;84:193-8. PMID: 10533775 .

5. Prisco ELG, Pinto CE, Barros AV, Reis GMS, Almeida HIB, Mello
ELR. Esofagectomia trans-hiatal versus transtorácica: experiência do Instituto Nacional do Câncer (INCA). Rev Col Bras Cir. 2010 May/June;37(3):167-74. doi: 10.1590/S0100-69912010000300003.

6. Vashist YK, Loos J, Dedow J, Tachezy M, Uzunoglu G, Kutup A, Yekebas EF, Izbichki JR. Glasgow prognostic score is a predictor of perioperative and long-term outcome in patients with only surgically treated esophageal cancer. Am Surg Oncol. 2011 Apr;18:1130-8. doi: 10.1245/s10434-010-1383-7.

7. Ando N, Ozawa S, Kitagawa Y, Shinozawa Y, Kitajima M. Improvement in the results of surgical treatment of advanced squamous esophageal carcinoma during 15 consecutive years. Ann Surg. 2000 Aug; 232(2):225-32. PMID: 1421135.

8. Gorman PO, Mc Millan DC, McArdle CS. Prognostic factors in advanced gastrointestinal cancer patients with weight loss. Nutr Cancer. 2000;37(1):36-40. PMID: 10965517.

9. Natsugoe S, Ikeda M, Bba M, Churei H, Hiraki Y, Nakajo M, Aikou T. Long-term survival of advanced esophageal cancer without surgical treatment: a multicenter questionnaire survey in Kyushu, Japan. Dis Esophagus. 2003;16:239-42. PMID: 14641317.

10. Mc Millan DC. An inflammation-based prognostic score and its role in the nutrition-based management of patients with cancer. Proc Nutr Soc. 2008 Aug;7:257-62. doi: 10.1017/S0029665108007131.

11. Mc Millan DC. Systemic inflammation, nutritional status and survival in patients with cancer. Curr Opin Clin Nutr Metab Care. 2009 May;12:223-6. doi: 10.1097/COM.0b013e32832a7902.

12. Mc Millan DC. The systemic inflammation-based Glasgow Prognostic Score: a decade of experience in patients with cancer. Cancer Treat Rev. 2013;39:534-40. doi: 10.1016/j.ctro.2012.08.003.

13. Cronk CE, Roche AF. Race and sex specific reference data for tríceps and subescapular skinfolds and weight/stature. Am J Clin Nutr. 1982 Feb;35:347-54. PMID: 7064895.

14. Blackburn GL, Bistrian BR, Maini BS, Schlamn HT, Smith MF. Nutricional and metabolic assessment of hospitalized patients. J Parenter Enteral Nutr. 1977 Aug;1:11-32. doi: 10.1177/01860717700100101.

15. Wang C, Hsieh MG, Chiu Yi C, Li SH, Huang HW, Fang FM, Huang YJ. Higher serum C. reactive protein concentration and hypoalbuminemia are poor prognostic indicators in patients with esophageal cancer undergoing radiotherapy. Radiother Oncol. 2009 Aug;92:970-5. doi: 10.1016/j.radonc.2009.01.002.

16. Braghetto MI, Cardemil HG, Mandiola BC, Masia LG, Gattini FS. Impacto da cirurgia minimamente invasiva no tratamento de câncer do esôfago. ABCD Arq Bras Cir Dig. 2014;27(4):237-42. doi: org/10.1590/50102-67202014000400003.

17. Eloubeidi MA, Desmond R, Arguelas MR, Reed CE, Wilcox CM. Prognostic factors for the survival of patients with esophageal carcinoma in the US. The importance of tumor length and lymph node status. Am Cancer Soc. 2002 Aug;95(7):1434-43. doi: 10.1016/j.radonc.2009.01.002.

18. Silva JB, Mauricio SF, Bering T, Correia MITD. The relationship between nutritional status and the Glasgow Prognostic Score in patients with cancer of the esophagus and stomach. Nutr Cancer. 2013;65(1):25-33. doi: 10.1080/01635581.2013.741755.

19. Andreyev HGN, Norman AR, Oates J, Cunninghan D. Why do patients with weight loss have a worse outcome when undergoing chemotherapy for gastrointestinal malignancies? Eur J Cancer. 1998 Mar;34:503-9. PIMD: 9713300.

20. Coussens LM, Werb Z. Inflammation and cancer. Nature. 2002 Mar;420:860-7. PMID: 9713300

21. Hourneaux G de Moura E, Sakai P, Cecconello I, Ishioka S. Palliative treatment of advanced esophageal cancer. Comparative study: autoexpandable metal stent and isoperistaltic esophagogastric bypass. Acta Gastroenterol Latinoam. 2001 Mar;31:13-22. PMID: 11370176. 
22. Crumley ABC, Mc Millan DC, Mc Kerman M, Mc Donald AC, Stwart RC. Evaluation of an inflammation-based prognostic score in patients with inoperable gastroesophageal cancer. Br J Cancer. 2006 Mar;94:637-41. PMID: 16479253.

23. Guillem P, Triboulet JP. Elevated serum levels of $\mathrm{C}$ reactive protein are indicative of a poor prognosis in patients with esophageal cancer. Dis Esophagus. 2005;18:146-50. PMID: 16045574.

24. Mc Millan DC, Watson WS, O'Gorman P, Preston T, Scott HR, Mc Ardle CS. Albumin concentrations are primarily determined by the body cell mass and the systemic inflammatory response in cancer with weight loss. Nutr Cancer. 2001; 39:210-3. doi: 10.1207/ S15327914nc392 8.

\section{Correspondence:}

Maria Aparecida Coelho de Arruda Henry

Faculdade de Medicina de Botucatu

Departamento de Cirurgia e Ortopedia-UNESP

Rua Miguel Cioffi, 200

18607-693 Botucatu - SP Brasil

Tel.: (55 14)3880-1447

Fax: (55 14)3811-2348

rhenry@ibb.unesp.br

Received: Apr 10, 2015

Review: June 13, 2015

Accepted: July 122015

Conflict of interest: none

Financial source: none

${ }^{1}$ Research performed at Department of Surgery, Gastroenterology Surgery Division and Department of Pathology, Investigative Pathology Division, Botucatu Medical School, Universidade Estadual Paulista (UNESP), Brazil. 